УДК 349.2:331.105.44

DOI https://doi.org/10.32849/2663-5313/2020.3.16

Зінаїда Білоус,

канд. юрид. наук

старший викладач кафедри господарського та адміністративного права

Національного технічного університету України

«Київський політехнічний інститут імені Ігоря Сікорського»

\title{
РОЛЬ ПРОФСПІЛОК У СФЕРІ НАГЛЯДУ I КОНТРОЛЮ ЗА ДОДЕРЖАННЯМ ЗАКОНОДАВСТВА ПРО ПРАЦЮ
}

Стаття присвячена дослідженню ролі профспілкових організачій у здійсненні громадського контролю за додержанням законодавства про пращю. Відстоюється думка, що профспілка є ключовим суб'єктом такого контролю та входить до складу органів, які забезпечують дотримання роботодавиями трудового законодавства. На прикладі Німеччини та Польщі продемонстровано природну необхідність участі профспілок у контрольно-наглядовій діяльності у сфері праці. Відстоюється думка, що сучасні тендениії вітчизняного трудового законодавства щодо його лібералізації зі звуженням прав профспілок є помилковими і не відповідають міжнародним зобов'язанням України та підходам до контрольно-наглядової діяльності у сфері прачі, що діють у розвинених державах. Прагнення нормотвориів звузити права профспілок щодо правових можливостей отримання інформації від роботодавия про умови та оплату прачі, а також позбавлення низки прав щодо перевірки сочіально-побутових умов пращі пращівників руйнують сощіально-партнерські відносини та наявні форми соиіального діалогу в Україні. У статті наголошено, що профспілка в Україні була й залишається ключовим суб'єктом громадського контролю за додержанням роботодавиями законодавства про прачю. Будь-які спроби звузити права профспілок щодо їхньої участі в прочесі правового забезпечення трудових та сочіальних прав прачівників є порушенням Конституції України. Здійснюючи громадський контроль за додержанням роботодавиями трудового законодавства, професійні спілки реалізують у такий спосіб своє функиіональне призначення. Профспілкова діяльність у сфері громадського контролю істотно впливає на загальний стан дотримання роботодавиями трудових прав працівників, зокрема і тих, які не є членами профспілкових організачій. Висловлено думку, що громадський контроль у сфері праиі має бути представлений не тільки профспілками, роботодавиями та їх об'єднаннями, а й іншими уповноваженими особами та органами. Сьогодні в Украйні та інших державах профспілкові об'єднання залишаються найчисельнішою громадською організачією, що покликана захищати трудові та соціальні права працівників.

Ключові слова: профспілка, громадський контроль, трудові права працівників, контрольнонаглядова діяльність у сфері праці, захист трудових прав працівників.

Постановка проблеми. В Україні проблематика нагляду і контролю за додержанням законодавства про працю та участі у цій діяльності профспілок певною мірою зумовлюється зміною державної політики у сфері праці з тенденціями до звуження прав профспілок [1]. Водночас нагляд і контроль за додержанням роботодавцями трудового законодавства залишається актуальною проблемою. Розвиток суспільних відносин в українському суспільстві, зміна соціальноекономічних умов суспільно корисної праці вимагає постійного оновлення та вдосконалення цієї системи. Останнім часом все частіше органи державної влади переконують нас у необхідності лібералізації трудового законодавства, що не завжди відповідає міжнародним зобов'язанням України. На наше переконання, недооцінка ролі профспілок у діяльності стосовно захисту прав працівників, а отже, і звуження їхніх прав $\epsilon$ помилкою. Дослідження ролі профспілок у реалізації контрольно-наглядових функцій потребує аналізу міжнародного досвіду. Це надасть можливість об'єктивно оцінити: (a) роль профспілок у сфері нагляду і контролю відповідно до сучасних підходів розвинених держав та (б) вітчизняну систему нагляду і контролю у сфері праці загалом.

Аналіз останніх досліджень та публікацій. Розвиток демократичних засад правового регулювання несамостійної праці, переоцінка ролі суб'єктів трудового права у правовому забезпеченні трудових прав та інтересів працівників вже тривалий час перебувають у полі зору науковців у галузі 
трудового права. Водночас питанню участі профспілок у здійсненні громадського контролю за додержанням роботодавцями законодавства про працю приділяється недостатньо уваги. Окремі аспекти цієї проблеми висвітлено у працях К. В. Гончарової, Ю. Ю. Івчук, О. Є. Костюченко, С. М. Прилипка, О. Г. Середи, А. М. Слюсара, О. М. Ярошенка та ін., проте погляд на проблему громадського контролю усферіпрацізурахуваннямсучаснихтенденцій розвитку трудового законодавства потребує окремої уваги.

Метою статті є обгрунтування та доведення ключової ролі профспілкових організацій у здійсненні та координуванні громадського контролю за додержанням роботодавцями законодавства про працю.

Виклад основного матеріалу. На початку періоду своєї незалежності Україна отримала у спадок систему нагляду і контролю у сфері праці, що характеризується відносинами між державою та адміністраціями державних підприємств, установ, організацій, а також між адміністраціями підприємства, установ, організації та профспілками. Втрата державою статусу єдиного роботодавця зумовила низку змін у відносинах між суб'єктами трудового права, проте законодавство щодо нагляду і контролю за додержанням законодавства про працю так і залишилося обтяженим застарілою ідеологією. Певною мірою це призвело до втрати профспілками своєї активності у відносинах з роботодавцями. А відсутність у працівників альтернативи щодо здійснення громадського контролю за додержанням роботодавцями трудового законодавства породила у роботодавців упевненість у їхній монополії на встановлення умов праці працівників, створення безпечних і здорових умов праці на власний розсуд. 3 часом це упевнило роботодавців у безкарності у разі порушень трудових прав працівників. У результаті цього в Україні сформувалися тенденції до звуження прав профспілок. Роль держави у сфері нагляду і контролю звелась до накладання на роботодавців штрафів, якими поповнюються відповідні державні фінансові фонди. За таких умов постає питання: чи дійсно в ринкових умовах діяльність профспілок у системі нагляду і контролю у сфері праці втрачає свою актуальність?

Так, відповідно до ч. 3 ст. 259 КЗпП Україні громадський контроль за додержанням законодавства про працю здійснюють профспілки та їх об'єднання [2]. Тобто в системі нагляду і контролю громадський контроль представлено виключно профспілками. Водночас, говорячи про діяльність державних та недержавних (профспілки) суб'єктів здійснення нагляду і контролю за додержанням законодавства про працю в Україні, необхідно виходити 3 того, що законодавство має враховувати головну відмінність у такій їхній діяльності. Ця відмінність «полягає в наявності у державних органів та інспекцій не лише контрольно-наглядових повноважень, а й владних повноважень, зокрема, давати роботодавцю обов'язкові для виконання приписи щодо усунення виявлених порушень, зупиняти діяльність підприємства або окремих його підрозділів у разі створення обстановки, небезпечної для життя і здоров'я працюючих, притягати винних до юридичної відповідальності» [3, с. 534]. Фактично профспілка у разі виявлення порушень роботодавцем законодавства про працю має правову можливість вимагати усунення таких порушень та має право представляти інтереси працівників в процесі захисту ними своїх трудових прав. Застосування санкцій до роботодавця у разі виявлення порушень $є$ правом держави в особі її органів та посадових осіб.

Водночас, відповідно до положень проекту Закону про внесення змін до деяких законодавчих актів України (щодо окремих питань діяльності професійних спілок) № 2681 від 27.12.2019, суб́'єкти законодавчої ініціативи пропонують змінити положення чинної ст. 248 КЗпП України, чим позбавити профспілки низки прав у сфері громадського контролю. Зокрема, виключити: право вимагати від роботодавця відомості та пояснення щодо умов праці, виконання колективних договорів, додержання законодавства про працю та соціально-економічних прав працівників; право перевіряти роботу закладів торгівлі, громадського харчування, охорони здоров'я, дитячих закладів, гуртожитків, транспортних підприємств і підприємств побутового обслуговування, що належать або надають послуги підприємству, установі, організації, в яких працюють члени профспілок; право перевіряти розрахунки 3 оплати праці та державного соціального страхування, використання коштів на соціальні і культурні заходи та житлове будівництво [1].

Занепокоєння також викликає бажання законотворців позбавити профспілки права на інформацію щодо умов та оплати праці, соціально-економічного розвитку підприємства [1]. Запропоновано внести зміни до ч. 1 ст. 251 КЗПП України, де передбачено виключити строк надання інформації профспілці. Тобто фактично роботодавець зобов'язаний надавати на запити профспілок, їх об'єднань інформацію щодо виконання колективних договорів і угод, 
але термін такої відповіді не визначено, тоді як сьогодні він становить тиждень [2]. Фактично запропонований законопроект руйнуе не лише одну з форм соціального діалогу, а й правовий спосіб отримання інформації профспілками задля виявлення порушень прав працівників щодо умов правці та їі оплати. Отже, якщо позбавити профспілку таких прав, то як здійснювати громадський контроль за додержанням законодавства про працю? Чому суб'єкти законодавчої ініціативи вважають, що контролю за виконанням колективного договору та колективних угод досить для громадського контролю у сфері праці? Як запропоновані положення забезпечують реалізації положень ст. 1 Конституції України, де закріплено, що Україна є соціальною державою?

У цьому контексті необхідно зазначити, що одними з критеріїв оцінки ступеня соціальності правової держави $є$ проведення активної й сильної соціальної політики та додержання прав і гарантій, що визначають і розвивають систему соціального партнерства як основного механізму досягнення громадської злагоди й балансу інтересів працівників і роботодавців при регулюючій ролі держави [4, с. 30-31].

3 практичного погляду цікавим у цьому контексті є досвід розвинених держав світу. Цінним для України є досвід побудови системи нагляду і контролю за додержанням законодавства про працю та залучення до цієї системи недержавних суб'єктів, зокрема профспілок. Так, контрольно-наглядову діяльність у сфері праці в Німеччині здійснюють: (а) вищі федеральні органи, зокрема Федеральне міністерство праці та соціальних справ та Федеральне міністерство внутрішніх справ; (б) органи місцевого самоврядування, зокрема виконавча влада земель Німеччини та муніципалітети; (в) зацікавлені особи, зокрема страхові компанії, спеціально уповноважені законом спеціалісти роботодавця (лікарі, спеціалісти з охорони праці та ін.), комітет з охорони праці та техніки безпеки i, відповідно, профспілки. Водночас німецькі профспілки наголошують, що в сучасних умовах нагляд і контроль за додержанням законодавства про працю в Німеччині потребує посилення. Мотивується це тим, що контроль, здійснюваний робочими радами та захист прав працівників з боку профспілок охоплюють лише частину трудових відносин, а накладання штрафів на роботодавців на користь державної скарбниці не покращує становища працівників [5, с. 11]. Зазначимо, що німецькі профспілки, здійснюючи громадський контроль у сфері праці, опікуються не лише питаннями умов праці членів проф- спілка. Як показує їхня практична діяльність, вони також опікуються питаннями умов праці працівників, що не є резидентами країни працевлаштування. Профспілка наголошує, що окремі Директиви ЄЄ у Німеччині реалізуються не досить ефективно, Директива 2014/67/ЕС від 15.05.2014 щодо введення в дію Директиви $96 / 71 / \mathrm{CC}$, стосовно розміщення працівників в рамках надання послуг і внесення поправок до Положення (СС) № 1024/2012 щодо адміністративного співробітництва через інформаційну систему внутрішнього ринку, на думку німецьких профспілок, не може зводитися виключно до накладання штрафів на порушників [5, с. 10].

Увага профспілкового об'єднання до цієї Директиви, на наше переконання, викликана тим, що іiі положення визначають правове регулювання трудових відносин 3 працівниками, які тимчасово, з метою надання послуг, перебувають в іншій державі-члені СС, ніж у тій, в якій він звичайно виконує свою роботу. При цьому положення цієї директиви спрямовані на допомогу органам нагляду і контролю виявляти нелегальних працівників, які проваджують діяльність не в країні свого громадянства, а також на виявлення неправдиво оголошених самозайнятих осіб [6]. Необхідністю підвищення ефективності реалізації положень вище названої Директиви зумовлюються і проблеми, пов’язані з шахрайством у сфері праці щодо роботи мобільних та сезонних працівників. Важливість цього питання зумовлена необхідністю захисту трудових прав таких працівників. Профспілки наголошують, що всі органі державної влади, зокрема ті, що здійснюють фінансовий контроль за нелегальною роботою, інспекції та асоціації страховиків, органи охорони здоров'я та безпеки праці, правоохоронні органи повинні контролювати законодавство у сфері праці з метою державного забезпечення трудових та соціальних прав працівників та виконання обов'язків, визначених колективними договорами [5, с. 11-12].

Тобто, незважаючи на наявність потужного державного апарату нагляду і контролю за додержанням трудового законодавства в Німеччині, виклики сучасності вимагають від держави постійного оновлення підходів до здійснення нагляду і контролю у зазначеній сфері, на чому і наполягають німецькі профспілки. Водночас принципово важливим є акцент на здійснення державного нагляду і контролю за додержанням трудових та соціальних прав працівників, а також тих прав, які закріплені в актах соціального партнерства. Досвід Німеччини щодо організації та правового забезпечення нагляду і контролю за додержанням законодавства про працю може бути запозичений Україною. 
Зокрема, це стосується множинності суб'єктів громадського контролю у сфері праці. Потужний профспілковий рух у Німеччині доводить, що, хоча додержання трудового законодавства та трудових прав працівників і перебуває під контролем держави, профспілкові об'єднання також відіграють важливу роль у цій діяльності.

Німецьке трудове законодавство та система нагляду і контролю за ним будується на юридичній силі договору та його свободі. Загальновідомий «німецький порядок», як національна культура та традиція, не дозволяє роботодавцям і працівниками порушувати свої договірні зобов'язання. Це доводить, що у Німеччині договір фактично є «універсальним правовим засобом, який дозволяє здійснювати як нормативне, так і індивідуальне правове регулювання» [7, с. 17]. Рівень правової культури німецького суспільства щодо дотримання трудового законодавства $€$ високим та повинен надихати українські профспілки до оптимізації їхньої діяльності щодо охорони й захисту трудових прав працівників. Діяльність німецьких профспілок як взірець для вітчизняних профспілкових організацій доводить, що діяльність цих професійних об'єднань залежить не від наявності деталізованого законодавства про їхню діяльність, а від бажання охороняти та захищати інтереси працівників. Проте важливо розуміти, що законодавство Німеччини не має тенденцій до звуження прав профспілок. Навпаки, німецькі профспілки реалізують свої права завдяки успішній реалізації соціального діалогу в суспільстві. Той факт, що німецькі профспілки турбуються про дотримання трудових прав працівників, які тимчасово працюють у Німеччині, доводить їхню принципову позицію щодо стану законності у сфері праці. Також діяльність німецьких профспілок щодо захисту трудових прав працівника та представлення його інтересів незалежно від членства у профспілці доводить, що спроби вітчизняних нормотворців звузити права профспілок $€$ необгрунтованими та практично помилковими.

Досвід Польщі також переконує у необхідності налагодження зв'язків між державою, роботодавцями та профспілками. У Польщі діє соціальна інспекція праці, діяльність якої врегульована спеціальним Законом [8]. Соціальна інспекція праці передбачає здійснення нагляду і контролю за умовами праці працівників, щоб забезпечити безпеку і гігієну праці на робочих місцях та виконання трудових обов'язків у питаннях охорони праці. Діяльність соціальної інспекції праці спрямована на захист інтересів працівників незалежно від їх членства у професійній спілці, проте діяльність цієї інспекції координується з профспілками.
Громадський контроль за додержанням трудового законодавства в Польщі здійснюється не лише профспілками, а й соціальним інспекторам праці. На наше переконання, множинність органів громадського контролю за додержанням законодавства про працю свідчить, що цей вид контролю є дієвим інструментом забезпечення трудових прав працівників. Також до органів громадського контролю за додержанням трудового законодавства в Польщі належить Комітет з охорони праці та безпеки, діяльність якого є обов'язковою на підприємствах, в установах, організаціях чисельністю понад 250 працівників. Система нагляду і контролю у сфері праці в Польщі з поєднанням участі громадськості у формуванні складу державних органів такого нагляду і контролю робить польську систему ефективною. Участь польських профспілок у здійсненні громадського контролю у сфері праці, а також їхні повноваження щодо координації діяльності соціальної інспекції праці доводить, що польська держава дбає про вирішення низки соціальних питань працездатного працюючого населення у трудових відносинах. Ми вважаємо, що публічність контрольно-наглядової діяльності у царині праці, що досягається через діяльність польських профспілок, стимулює роботодавців до додержання законодавства про працю задля підтримки та підвищення своєї репутації гідного партнера у договірних відносинах.

Говорячи про роль профспілок в Україні у здійсненні громадського контролю за додержанням роботодавцями законодавства про працю, необхідно зазначити, що «в Україні до сьогодні немає громадської організації, яка б могла конкурувати із профспілками щодо досвіду роботи у сфері колективно-договірного регулювання умов праці» [9, с. 127]. А отже, профспілки в Україні є найпотужнішою організацією, яка наділена правом захищати трудові та соціальні права працівників. Ми погоджуємося з думкою про те, що поряд із державними органами профспілкові організації є суб'єктами, діяльність яких пов'язана із забезпеченням трудових прав і законних інтересів працівників [10, с. 88-89]. Вважаємо, що профспілки виступають одним із ключових суб'єктів правового забезпечення трудових прав та інтересів працівників. У цьому контексті погоджуємося з твердженням про те, що запобігання порушенням трудового законодавства, пов'язаним з умовами праці, здійснюється засобами попереднього нагляду і контролю, що здійснюється роботодавцем спільно чи за погодженням, чи з урахуванням думки виборного профспілкового органу або іншого уповноваженого на представництво трудом колективом органу [11, с. 313]. 


\section{Висновки}

Профспілка в Україні була і залишається ключовим суб'єктом громадського контролю за додержанням роботодавцями законодавства про працю. Будь-які спроби звузити права профспілок щодо їхньої участі в процесі правового забезпечення трудових та соціальних прав працівників є порушенням Конституції України. Громадський контроль у сфері праці має бути представлений не тільки профспілками, роботодавцями та їх об'єднаннями, а й іншими уповноваженими особами та органами. Сьогодні профспілки залишаються найчисленнішою громадською організацією, метою якої є захист трудових прав працівників. Досвід Німеччини та Польщі доводить, що діяльність профспілок є необхідним елементом загальної системи нагляду і контролю у сфері праці. Здійснюючи громадський контроль у сфері праці, професійні спілки реалізують своє функціональне призначення. Профспілкова діяльність у сфері громадського контролю істотно впливає на загальний стан дотримання роботодавцями трудових прав працівників, зокрема і тих, які не є членами профспілкових організацій.

\section{Список використаних джерел:}

1. Проект Закону про внесення змін до деяких законодавчих актів України (щодо окремих питань діяльності професійних спілок) № 2681 від 27.12.2019. URL: http://w1.c1.rada.gov.ua/ pls/zweb2/webproc4_1?pf3511=67792 (дата звернення: 28.02.2020)

2. Кодекс законів про працю України. Вiдомості Верховної Ради УРСР. 1971. № 50. Ст. 375.
3. Трудове право : підручник / О. М. Ярошенко, С. М. Прилипко, А. М. Слюсар та ін.; за заг. ред. О. М. Ярошенка. 2-ге вид., переробл. і допов. Харків : Право, 2017. 560 с.

4. Держава та ï органи як суб єкти трудового права: теоретико-прикладний нарис : монографія / К. В. Гончарова, Ю. Ю. Івчук, С. М. Прилипко, О. М. Ярошенко; за наук ред. проф. О. М. Ярошенка. Харків: Право, 2014. 288 с.

5. Arbeitsinspektion in einer globalisierten Welt: Ein Positionspapier der Deutschen Kommission Justitia et Pax und des Deutschen Gewerkschaftsbundes (DGB). Bonn. Berlin. 2017.25 p.

6. Directive $2014 / 67 / \mathrm{EU}$ of the European parliament and of the Council of 15 May 2014 on the enforcement of Directive 96/71/EC concerning the posting of workers in the framework of the provision of services and amending Regulation (EU) No 1024/2012 on administrative cooperation through the Internal Market Information System ('the IMI Regulation'). Official Journal of the European Union. 28.5.2014. L 159/11- L 159/31.

7. Погребняк С.П. Договір: загальнотеоретична характеристика. Договір як універсальна правова конструкиія : монографія / А.П. Гетьман, В.І. Борисова, О.П. Євсєєв та ін.; за ред. А.П. Гетьмана, В.І. Борисової. Харків: Право, 2012. С. 13-25.

8. Społeczna Inspekcja Pracy ustawie z dnia 24 czerwca 1983. Dziennik Ustaw, 1983, Nr 35, poz. $163 \mathrm{z}$ późn. Zm.

9. Костюченко О.Є. Державне і договірне регулювання відносин у сфері праці : монографія. Київ : УБС НБУ, 2011. 187 с.

10. Костюченко О. Є. Реалізація соціального призначення трудового права в Україні : монографія. Харків : Право, 2018. 392 с.

11. Середа О. Г. Державно-правовий механізм захисту прав працівників в умовах інтеграції України до Європейського Союзу: теорія та практика : монографія. Харків : Право, 2018. 472 с.

The article is devoted for researching the role of trade union organizations in the implementation of public control over compliance with labor law. Defending the idea that the union is a key subject of such control and it is a part of bodies, which enforce employers' labor laws. The example of Germany and Poland demonstrates the natural need for the participation of trade unions in supervisory and labor activities. It is argued that the current tendencies of domestic labor legislation on its liberalization are erroneous, where trade union rights are narrowed, and they are not in line with Ukraine's internationalobligations and approaches to work-related supervisory activities in developed countries. The desire of the lawmakers to narrow the rights of trade unions on the legal possibilities of obtaining information from the employer about the conditions and remuneration, as well as the deprivation of a number of rights to check the social and living conditions of workers are destroying socialpartner relations and existing forms of social dialogue in Ukraine.The article emphasized that the trade union in Ukraine has been and remains a key subject of public control over employers' compliance with labor laws. Any attempt to narrow the rights of trade unions to participate in the process of legal protection of labor and social rights of workers is a violation of the Constitution of Ukraine. In public controlling over employers' compliance with labor law, the trade unions implement their functional purpose in this way. The trade union activities in the field of public oversight have a significant impact on the general status of employers' observance of labor rights of employees, including those who are not members of trade union organizations. It is suggested that public control in the sphere of work should be represented not only by trade unions, employers and their associations, but also by other authorized persons and bodies, but today in Ukraine and other states trade union organizations stay the largest public organization, which defends the work and social rights of employees.

Key words: trade union, public control, labor rights of workers, control and supervision in the sphere of work, protection of labor rights of workers. 